\title{
Genetic and environmental determinants of the urea level in cow's milk
}

\author{
A. Czajkowska ${ }^{1}$, B. Sitkowska ${ }^{1}$, D. Piwczyński ${ }^{1}$, P. Wójcik ${ }^{2}$, and S. Mroczkowski ${ }^{1}$ \\ ${ }^{1}$ University of Technology and Life Sciences, Faculty of Animal Breeding and Biology, Department of \\ Genetics and General Animal Breeding, Bydgoszcz, Poland \\ ${ }^{2}$ National Research Institute of Animal Production, Balice, Poland \\ Correspondence to: B. Sitkowska (sitkowskabeata@gmail.com)
}

Received: 25 March 2014 - Accepted: 10 December 2014 - Published: 4 March 2015

\begin{abstract}
This study was conducted on a sample of 2237 Polish Holstein-Friesian cows. The aim was to estimate the effect of selected environmental factors on the level of urea in cow's milk and on its genetic parameters, i.e. the heritability coefficients, and genetic correlation with other selected traits of milk production. The present study has revealed the existence of a highly significant influence of herd, year of calving, parity, lactation phase, and milk performance level on the urea content in cow's milk. A high urea level in milk was detected in samples collected from older animals, both during the winter season and the middle phase of lactation (101-200 days).

The heritability estimates were generally at a low level, particularly in terms of milk yield (0.183) and urea content (0.152-0.159), which may indicate the dominant role of the environment in shaping them. Relatively low values of genetic correlation $(-0.097-0.140)$ between the urea content and other traits suggest that improvement of milk yield and its composition modify the urea level in milk only to a small degree.
\end{abstract}

\section{Introduction}

An appropriate cow feeding programme is a major factor in high milk production. Many authors (Aguilar et al., 2012; Biswajit et al., 2011; Geerts et al., 2004; Hojman et al., 2004; Oltner et al., 1985) are of the opinion that, for dairy cows, the level of urea in cow's milk (MU, milk urea) may be the indicator of whether the energy balance and protein ratio are proper. In general, in properly balanced feed, the MU ratio is at $15-30 \mathrm{mg} \mathrm{dL}^{-1}$. However, it should be noted that, for accurate interpretation of the urea content, not only the feed factor but also other factors should be taken into consideration. These factors include breed (Rodriguez et al., 1997), parity (Broderick and Clayton, 1997; Godden et al., 2001; Sawa et al., 2011), body weight (Kohn et al., 2002), milk yield (Godden et al., 2001), fat and protein content, days in milk (DIM), milking frequency (Godden et al., 2001; Kgole et al., 2012), and month of the year (Arunvipas et al., 2003; Biswajit et al., 2011; Borkowska et al., 2012; Frand et al., 2003; Hojman et al., 2004; Kgole et al., 2012; Oudah, 2009; Rafieei, 2011; Rzewuska and Strabel, 2013b). In Pol- ish breeding programmes, urea content in cow milk has been monitored since 2000.

Milk urea nitrogen (MUN), which is commonly used for monitoring feeding programmes implemented in order to achieve environmental goals, is correlated with nitrogen balance, intake, and dietary content (Aguilar et al., 2012; Jonker et al., 1999; Kř́žzová et al., 2013). Urea is the end product of protein metabolism. Excess protein is not excreted by the cow and is usually broken down into ammonia. Ammonia is toxic to animal tissues, and is therefore rapidly converted to urea in the liver. Urea is measurable in both blood and milk (Rajala-Schultz et al., 2001). A low level of urea may be due to protein deficiency; on the other hand, too high a content may be the result of excess protein delivered by feed. Monitoring the level of urea in milk can provide valuable information on the cow's nutritional state and health (Geerts et al., 2004; Rajala-Schultz et al., 2001). Hojman et al. (2004) reported that production and environmental factors account for $37 \%$ of the variation in MU. Arunvipas et al. (2003) stated that factors such as breed, parity, days in milk, milk production, milk quality, and milk components were responsible 
for $13.3 \%$ of the variation in MUN concentration. RajalaSchultz et al. (2001) indicate that increased MUN levels appeared to be negatively related to dairy cow fertility.

The aim of the present study was to evaluate the effect of the selected environmental factors on the level of urea in cow's milk and its genetic parameters, i.e. the heritability coefficients and genetic correlation with other selected traits of milk production.

\section{Material and methods}

\subsection{Animals and treatments}

The study was conducted on 2237 cows of the Polish Holstein-Friesian (PHF) breed, born between 2004 and 2009, and reared for their milk in three high-performance herds localized in Poland. Cows calved between 2006 and 2012. The housing, nutrition, and milking conditions were different across the herds. Cows were kept in free-stall barns, on litter. In herds A and B, the buildings were new, whereas the building for herd C is a free-stall barn built in the 1970s (upgraded from a tie-stall barn). On all farms, the production cycle was closed, and production groups were determined based on production volume. In herds A and B, milking is done in a herringbone parlour manufactured by Afimilk; herd $\mathrm{C}$ is milked in a rotary parlour. The total mixed ration (TMR) feeding method was used for all herds. In herd A, animal feed was produced on the farm based on own silage made of lucerne, straw, hay, or purchased feed, which is soya, brewer's grains, post-extraction soya meal, and pea meal. In herd B, feeding was based on wilted silage, maize silage, and dried brewer's grains, as well as rapeseed and soya meals. In herd $\mathrm{C}$, animals were fed with wilted silages or maize silage, and the ration also included straw and wet sugar beet pulp, as well as soya, rapeseed, and grain meal.

The levels of urea in milk, milk yield in test milking, content $(\%)$ of fat, protein, lactose, and dry matter in 36902 test milkings were all controlled. The variation in the traits was examined based on the following factors: herd (A-C), parity $(1,2, \geq 3)$, milking season (spring, summer, autumn, winter), lactation phase (5-100, 101-200, 201-305 days), daily yield of milk ( $\leq 25.0 ; 25-32,32-39 ;>39 \mathrm{~kg})$, and year of cow's birth $(2004, \ldots, 2009)$.

Statistical calculations were conducted with the use of results from test milkings, which took place between lactation days 5 and 305 .

The number of cows included in the output data set used in the genetic analysis was reduced from 2237 to 1825 , due to several of the applied criteria. The only data taken into consideration were those from cows for which the number of test milkings in a lactation was at least six, and the last test milking took place after lactation day 200. At least 10 cows per herd $x$ year of birth were required. The average number of animals in a herd $x$ year or birth class (18 classes) was 124 . Cows were omitted if their sire had less than 10 daughters. The cows assessed in terms of their lactation traits were daughters of 145 bulls. In total, these data were placed in 943 HTD (herd test day) classes.

The pedigree information of the studied animal population was, where possible, gathered up to the third generation. Using the INBREED procedure of the SAS package (SAS, 2013), we examined the population inbreeding level. The resultant rate in reference to 13 inbred animals was $22.92 \%$ ( standard deviation $=4.87 \%$ ).

\subsection{Explorative analysis}

In order to statistically evaluate the impact of the abovementioned factors on the analysed features, the multifactor analysis of variance was used. The linear model describing the variability of milk production traits, in addition to the impact of the main factors - herd, milking season, lactation phase, daily yield of milk, and year of cow's birth - takes into consideration all first-order interactions between the main factors. The significance of differences between groups was examined by using the Bonferroni test. Calculations were performed with the SAS statistical package.

\subsection{Genetic analysis}

We evaluated indicators of heritability, as well as the genetic correlation between the urea content and both milk yield during test milking and milk composition, i.e. the content (\%) of fat, protein, lactose, and dry matter.

Estimation of parameters was performed with the use of the restricted maximum likelihood (REML) method and the REMLF90 software (Misztal, 2007). While estimating genetic parameters with the REML method, the same convergence index, equal to $10^{-10}$, was adopted for all models. Genetic parameters of studied traits were estimated using twotraits linear classification models (animal models). The same models were used for each of the analysed features:

$$
\begin{aligned}
y_{i j l m}= & \mathrm{HTD}_{i}+\sum_{k=1}^{3} b_{j k} \times z_{l m k}+\sum_{k=1}^{3} a_{l k} \times z_{l m k} \\
& +\sum_{k=1}^{3} p_{l k} \times z_{l m k}+e_{i j l m},
\end{aligned}
$$

where $y_{i j l m}=$ test day (TD) record $m$ for MU, milk, fat, protein, lactose, and dry matter of cow $i$ belonging to parity subclass $j ; \mathrm{HTD}_{i}-$ fixed herd - TD effect; $k-k$ th parameter of Legendre polynomials; $b_{j k}$ - fixed regression coefficients specific to parity subclass $j ; a_{l k}$ - random regression coefficients specific to additive genetic effect of cow $1 ; p_{l k}$ - random permanent environmental effect associated with all TD yields of cow $m ; e_{i j l m}$ - random residual effect; and $z_{l m k}-$ Legendre polynomials modified by Gengler et al. (1999):

$$
z_{0}=1 ; z_{1}=\sqrt{3 x} ; z_{2}=\sqrt{5 / 4\left(3 x^{2}-1\right)},
$$


Table 1. Descriptive statistics of the analysed traits $(N=36902)$.

\begin{tabular}{lrr}
\hline Trait & Mean & Standard deviation \\
\hline MU, mg dL $^{-1}$ & 20.64 & 7.92 \\
Milk, kg & 32.74 & 9.50 \\
Fat, \% & 3.73 & 0.83 \\
Protein, \% & 3.37 & 0.33 \\
Lactose, \% & 4.89 & 0.21 \\
Dry matter, \% & 12.61 & 1.00 \\
\hline
\end{tabular}

where $x=-1+2 \times(\mathrm{DIM}-5) /(305-5)$; DIM - days in milk.

These are model assumptions, as well as variance and co-variance components necessary for estimating heritability coefficients and genetic correlations for particular lactation days (from day 5 to 305), calculated based on formulas proposed by Jamrozik and Schaeffer (1997).

\section{Results and discussion}

Table 1 shows arithmetic means and standard deviations for the analysed traits in the data set. The results of our study indicate that the average level of urea in milk is approximately $20.64 \mathrm{mg} \mathrm{dL}^{-1}$, which may be considered to be a normal result (Table 1). Other studies (Sawa et al., 2011) have shown that, in the case of feeding dairy cows, the most optimal urea concentration in milk is $15-30 \mathrm{mg} \mathrm{dL}^{-1}$. According to many authors (Rajala-Schultz et al., 2001; Sawa et al., 2011), monitoring the concentration of urea in cow's milk may enable identification of the causes of health problems in cows which mainly affect fertility.

On the basis of the calculated standard deviation (7.92 $\mathrm{mg} \mathrm{dL}^{-1}$ ), it may be concluded that the urea content in milk was characterized by a high dispersion. In the study of Jonkus and Paura (2011), who conducted their studies on Latvian Brown cows, the average MU was found to be at a level of $16.55 \mathrm{mg} \mathrm{dL}^{-1}$ and milk yield per test day was at a level of $20.37 \mathrm{~kg}$. The average milk yield in the test milking was $32.74 \mathrm{~kg}$ and the content of fat and protein was 3.73 and $3.37 \%$, respectively. The lactose and dry matter content was 4.89 and $12.61 \%$, respectively (Table 1 ). The results indicate that tested herds were characterized by significantly higher milk parameters in comparison to the average results obtained for the population that had been evaluated in Poland in 2012 (PFHBiPM, 2012).

By using the multifactor analysis of variance it was proven that factors which highly significantly and significantly differentiated the level of urea in cow's milk, milk yield, and its composition were herd, parity, lactation phase, season of test milking, and year of birth (Table 2). In addition, the factor that statistically affected the level of urea in milk and milk content traits was the level of milk yield. Furthermore, a statistical effect of the majority of interactions included in the classification model for the analysis of interaction variance was shown. Jonkus and Paura (2011) reported that milk productivity traits were affected by factors such as season, parity, and lactation phase $(P<0.001)$, with the exception of fat content, which was not affected by parity. Season and milking systems influenced MU $(P<0.001)$. Kgole et al. (2012) noted that MUN was significantly affected by herd test day, year of calving, parity, number of milkings per day, and the lactation phase.

Due to the initial aim of the study, the next stage of description included an interpretation of the results for the analysis of variance and Bonferroni test, relating to the urea content in cow's milk.

The level of urea in milk varied depending on the herd. In herd $\mathrm{C}$, the average level of this component was the highest and amounted to $22.63 \mathrm{mg} \mathrm{dL}^{-1}$, while in herd A the level was the lowest at $17.77 \mathrm{mg} \mathrm{dL}^{-1}$. Such variation in the value of the urea level may suggest that different feeding systems were used in those herds (Table 3). Those results are in accordance with Carlsson et al. (1995), Godden et al. (2001), Hojman et al. (2004), and Rodriguez et al. (1997), who also obtained results that were not the same due to differences in feeding. Changes in the level of urea may be caused by a cow's individual physiology, different feeding programmes, rearing, or breed.

Taking parity into account, it was proven that the level of urea was the highest during the first lactation and the lowest during the third one (Table 3). According to Fatehi et al. (2012) and Jílek et al. (2006), the mean MUN concentration, reported for Holstein cows in the third and later lactations, was lower than in the first or second lactation. Opposite results were obtained by Bendelja et al. (2011), who noted that the lowest urea concentration in milk was during the first lactation. Also, according to Carlsson et al. (1995) and Godden et al. (2001), MUN concentrations were lowest during the first lactation.

Studies reporting lower MUN values in the first lactation suggested that primiparas were still growing and therefore might have used amino acids more effectively (Arunvipas et al., 2003; Canfield et al., 1990; Carlsson et al., 1995; Ferguson et al., 1997; Ng-Kwai-Hang et al., 1985; Oltner et al., 1985). According to Doska et al. (2012), primiparas showed higher MUN values compared to multiparas, which may be explained by the lower milk production of younger cows. Moreover, Hojman et al. (2004) reported the association between high MU levels and high milk yields.

It was proven that the season of the test milking differentiated urea level (Table 2). The highest urea content was noted in milk of cows milked in winter and spring and the lowest in cows milked in summer (Table 3 ).

The increased level of urea in milk may be caused by excess of protein in feed, too small an amount of easily fermentable carbohydrates in rumen, excess protein which degrades in rumen too rapidly, too low an intake of water, detoxification processes that excessively burden the liver, and energy losses that arise from the rearing conditions. On the 
Table 2. The significance of the impact of the tested factors on the level of the urea in cow's milk.

\begin{tabular}{|c|c|c|c|c|c|c|}
\hline Factor & Milk, kg & $\mathrm{MU}, \mathrm{mg} \mathrm{dL}^{-1}$ & Fat, $\%$ & Protein, $\%$ & Lactose, \% & Dry matter, $\%$ \\
\hline Herd $(\mathrm{H})$ & $893.18 * *$ & $876.34 * *$ & $297.21 * *$ & $41.89 * *$ & $133.87 * *$ & $186.58 * *$ \\
\hline Lactation (L) & $704.01 * *$ & $17.65 * *$ & $125.19 * *$ & $84.08 * *$ & $660.78 * *$ & $63.31 * *$ \\
\hline Season of TD (S) & $62.55^{* *}$ & $203.72 * *$ & $166.18 * *$ & $319.07 * *$ & $40.74 * *$ & $284.32 * *$ \\
\hline Phase of lactation $(\mathrm{P})$ & $3779.03 * *$ & $322.16^{* *}$ & $116.75 * *$ & $1246.48 * *$ & $88.56 * *$ & $42.73 * *$ \\
\hline Level of $24 \mathrm{~h}$ yield (M) & & $176.47 * *$ & $993.2 * *$ & $656.14 * *$ & $531.09 * *$ & $930.32 * *$ \\
\hline Year of birth (Y) & $121.87 * *$ & $69.28 * *$ & $29.21 * *$ & $15.76^{* *}$ & $12.36^{* *}$ & $36.26 * *$ \\
\hline $\mathrm{H} \times \mathrm{L}$ & $153.83 * *$ & $67.62 * *$ & $5.13 * *$ & $26.27 * *$ & $8.16^{* *}$ & $3.03 *$ \\
\hline $\mathrm{H} \times \mathrm{S}$ & $4.12 * *$ & $21.13 * *$ & $8.24 * *$ & $13.15^{* *}$ & $9.31 * *$ & $13.68 * *$ \\
\hline $\mathrm{H} \times \mathrm{P}$ & $25.75 * *$ & $10.10 * *$ & $34.11 * *$ & $37.11 * *$ & $9.30 * *$ & $16.60 * *$ \\
\hline $\mathrm{H} \times \mathrm{M}$ & & $14.09 * *$ & $11.99 * *$ & $18.35^{* *}$ & $4.07 * *$ & $9.53 * *$ \\
\hline $\mathrm{H} \times \mathrm{Y}$ & $41.12 * *$ & $129.85^{* *}$ & $11.87 * *$ & $37.11 * *$ & $7.42 * *$ & $19.63 * *$ \\
\hline $\mathrm{L} \times \mathrm{S}$ & 1.19 & $94.61 * *$ & $3.33 * *$ & $4.73 * *$ & $13.91 * *$ & $4.25 * *$ \\
\hline $\mathrm{L} \times \mathrm{P}$ & $300.30 * *$ & $40.43 * *$ & $10.57 * *$ & $8.56 * *$ & $4.19 * *$ & $9.46 * *$ \\
\hline $\mathrm{L} \times \mathrm{M}$ & & $13.53 * *$ & $18.38 * *$ & $11.94 * *$ & $35.87 * *$ & $24.81 * *$ \\
\hline $\mathrm{L} \times \mathrm{Y}$ & $3.23^{* *}$ & $45.73 * *$ & $6.19 * *$ & $21.82 * *$ & $7.01 * *$ & $16.98 * *$ \\
\hline $\mathrm{S} \times \mathrm{P}$ & $39.85 * *$ & $3.38 * *$ & $13.67 * *$ & $11.59 * *$ & 1.68 & $13.73 * *$ \\
\hline $\mathrm{S} \times \mathrm{M}$ & & 1.83 & $4.27 * *$ & $1.98^{*}$ & $2.91 * *$ & $3.05 * *$ \\
\hline $\mathrm{S} \times \mathrm{Y}$ & 1.50 & $75.30 * *$ & $3.72 * *$ & $4.17 * *$ & $19.10 * *$ & $4.86^{* *}$ \\
\hline $\mathrm{P} \times \mathrm{M}$ & & $11.23 * *$ & $4.76 * *$ & $2.96 * *$ & $18.10 * *$ & $4.15^{* *}$ \\
\hline $\mathrm{P} \times \mathrm{Y}$ & $2.60 * *$ & $5.46^{* *}$ & 0.98 & $4.41 * *$ & $5.50 * *$ & $1.85^{*}$ \\
\hline $\mathrm{M} \times \mathrm{Y}$ & & $7.52 * *$ & $3.65^{* *}$ & $10.39 * *$ & $8.70 * *$ & $7.10 * *$ \\
\hline
\end{tabular}

** $P \leq 0.01, * P \leq 0.05$

other hand, too low a level of urea in cow's milk may arise from an insufficient level of protein in feed, the excess of easily fermentable carbohydrates (feed concentrates), incorrectly balanced feed ratio, and malnutritio that not necessarily inhibit the potential productivity of dairy cows (Jonker et al., 1999). Doska et al. (2012) reported that the concentrations of milk urea nitrogen were found to be higher $(P<0.01)$ during winter, intermediate in spring, and low in both autumn and summer. This result is in contrast to those results obtained by Sawa et al. (2011), Godden et al. (2001), Ferguson et al. (1997), and Wattiaux et al. (2005), who also noted that milk urea varied depending on the month and season. They did, however, notice that the highest milk urea level was obtained during the summer months. In the study conducted by Fatehi et al. (2012), MUN was found to be the lowest in December and the highest in July. Hojman et al. (2004) obtained the lowest MUN level in November and the highest in June. According to Bendelja et al. (2011), the urea concentration in milk was significantly higher $(P<0.01)$ in spring and summer than during other seasons. According to Křížová et al. (2013), the concentration of nitrogen fractions decreased during summer, while during winter it was higher $(P<0.05)$. Rzewuska and Strabel $(2013 a)$ reported the association between the sampling month, air temperature, and MU. MU was high during the period from May to October, and the highest values were recorded in the summer months. However it should be noted that, regardless of the season, MU increased with increasing temperatures.
Another factor that was found to affect the level of urea in cow's milk was the phase of lactation. In the present research the highest level of urea was found in samples collected between 101 and 200 days of lactation, while the lowest was noted during the first stage of lactation, which results from the natural physiology of cows after calving (Table 3). At the beginning of lactation, the increase in the milk yield is accompanied by a lack of appetite, which in turn leads to a reduced intake of feed. In later periods of lactation, appetite as well as the milk yield and the level of urea in milk increases (Godden et al., 2001).

Fatehi et al. (2012) reported that the concentration of MUN in milk was the lowest during the first 30 days. Godden et al. (2001) obtained the lowest MU during the first 60 days of lactation, while MU in milk was higher between 60 and 150 days. After approximately 150 days of lactation, MU decreased. Also, in the study of Doska et al. (2012), the impact of the lactation phase on MUN was found to be significant, as the highest MUN values were observed in the sixth month of lactation.

In the present study it was noted that while the daily performance increased, the level of urea increased as well. The differences between the tested samples were highly significant (Table 3). The results are in accordance with the tendency presented by Carlsson et al. (1995) and Rajala-Schultz and Saville (2003).

Calculated averages suggest that the urea content in the milk of cows born between 2004 and 2007 was similar. Dif- 
Table 3. Level of urea in milk with respect to selected factors.

\begin{tabular}{|c|c|c|c|c|}
\hline Factors & Level & $\begin{array}{l}\text { Number of } \\
\text { samples }\end{array}$ & $\begin{array}{l}\text { Mean, } \\
\mathrm{mg} \mathrm{dL}^{-1}\end{array}$ & $\begin{array}{l}\text { Standard } \\
\text { deviation }\end{array}$ \\
\hline \multirow[t]{3}{*}{ Herd } & A & 12621 & $17.77^{\mathrm{A}}$ & 9.16 \\
\hline & B & 12684 & $21.66^{\mathrm{AB}}$ & 5.79 \\
\hline & $\mathrm{C}$ & 11597 & $22.63^{\mathrm{AB}}$ & 7.58 \\
\hline \multirow[t]{3}{*}{ Lactation } & 1 & 17815 & $20.79^{\mathrm{A}}$ & 7.98 \\
\hline & 2 & 10597 & 20.59 & 7.97 \\
\hline & $\geq 3$ & 8490 & $20.39^{\mathrm{A}}$ & 7.71 \\
\hline \multirow[t]{4}{*}{ Season of TD season } & Spring & 10997 & $21.07^{\mathrm{A}}$ & 7.70 \\
\hline & Summer & 7267 & $18.86^{\mathrm{AB}}$ & 7.16 \\
\hline & Autumn & 8689 & $20.04^{\mathrm{ABC}}$ & 7.90 \\
\hline & Winter & 9949 & $21.98^{\mathrm{ABC}}$ & 8.39 \\
\hline \multirow[t]{3}{*}{ Lactation phase } & 5-100 days & 13342 & $19.71^{\mathrm{A}}$ & 8.02 \\
\hline & $101-200$ days & 12796 & $21.89^{\mathrm{AB}}$ & 7.86 \\
\hline & 201-305 days & 10764 & $20.29^{\mathrm{AB}}$ & 7.67 \\
\hline \multirow[t]{4}{*}{$24 \mathrm{~h}$ yield, $\mathrm{kg}$} & $\leq 25.0$ & 7579 & $18.23^{\mathrm{A}}$ & 8.23 \\
\hline & $>25.0 \leq 32.0$ & 9922 & $20.19^{\mathrm{AB}}$ & 8.09 \\
\hline & $>32.0 \leq 39.0$ & 10334 & $21.78^{\mathrm{AB}}$ & 7.76 \\
\hline & $>39.0$ & 9067 & $21.84^{\mathrm{AB}}$ & 7.09 \\
\hline \multirow[t]{6}{*}{ Year of birth } & 2004 & 1654 & $19.73^{\mathrm{A}}$ & 8.53 \\
\hline & 2005 & 3555 & $19.59^{\mathrm{B}}$ & 7.85 \\
\hline & 2006 & 8645 & $19.72^{\mathrm{C}}$ & 7.62 \\
\hline & 2007 & 7336 & $19.41^{\mathrm{D}}$ & 8.00 \\
\hline & 2008 & 8589 & $21.08^{\mathrm{ABCDE}}$ & 7.88 \\
\hline & 2009 & 7123 & $23.22^{\mathrm{ABCDE}}$ & 7.46 \\
\hline
\end{tabular}

AA - means marked with identical capital letters differ $(P \leq 0.01)$

ferences that were proven to be statistically significant were found between the above-mentioned years and the year 2009 and 2008. This may suggest that some changes in feeding programmes used in those years were made (Table 3). Monitoring the urea content in milk may allow the status of nutrition and cow's health to be controlled. It would also allow protein efficiency in dairy cows to be evaluated in order to optimize the efficiency of utilization of the dietary protein (Guo, 2004).

Heritability of the tested milk traits was at a low or moderate level: milk yield -0.183 ; $\mathrm{MU}-0.152-0.159$; fat content - 0.271; protein content -0.327 ; lactose content -0.340 ; and dry matter -0.298 . Genetic correlation indices $\left(r_{\mathrm{g}}\right)$ showed that the urea content in milk was negatively correlated with milk yield $\left(r_{\mathrm{g}}=-0.097\right)$, positively correlated with fat content $\left(r_{\mathrm{g}}=0.140\right)$ and dry matter $\left(r_{\mathrm{g}}=0.125\right)$, and very weakly correlated with protein $\left(r_{\mathrm{g}}=0.038\right)$ and lactose content $\left(r_{\mathrm{g}}=0.071\right)$ (Table 4$)$. Rzewuska and Strabel (2013a) reported that the average daily heritabilities of MU were 0.22 for the first and 0.21 for the second and third lactations. Hossein-Zadeh and Ardalan (2011) reported that the average genetic correlation for MUN and lactose percent- age was close to zero $(-0.01)$, while the average genetic correlation was moderately positive for milk yield (0.24), net energy concentration of milk $(0.31)$, fat $(0.21)$, and protein percentage $(0.30)$. Average estimated heritabilities for MUN ranged from 0.14 to 0.21 throughout lactations. In the studies of Mucha and Strandberg (2011), the estimated MUN heritability was stable during the whole lactation and ranged between 0.16 and 0.18 . According to Kramer et al. (2013), who calculated heritabilities for Brown Swiss cattle for each udder, the quarters were in the following ranges: fat content $0.09 \pm 0.06$ to $0.14 \pm 0.06$, protein $0.20 \pm 0.09$ to $0.33 \pm 0.07$, lactose $0.04 \pm 0.03$ to $0.16 \pm 0.07$, and urea $0.13 \pm 0.07$ to $0.22 \pm 0.08$. Jonkus and Paura (2011) described the effect of the season, parity, and lactation phase $(P<0.001)$ on milk productivity traits, although they reported the exception of fat content, which was not affected by parity. Moreover, they stated that MU depended on the season and milking systems $(P<0.001)$ and that the estimated MU heritability (0.072) was low for milk production traits.

The estimated MU heritability values during a 305-day lactation fluctuated between 0.139 and 0.194 (Fig. 1). The highest values were found in the first 30 and the last 20 days 
Table 4. Estimates of (co)variance components, heritability and repeatability of milk yield, milk composition calculated based on the bivariate linear-linear models.

\begin{tabular}{llrlrrr}
\hline Estimate & Traits included & \multicolumn{5}{c}{ Traits (X) } \\
\cline { 3 - 7 } & in the model & Milk, kg & Fat, \% & Protein, \% & Lactose, \% & Dry matter, \% \\
\hline$\sigma_{\mathrm{a}}^{2}$ & $\mathrm{X}$ & 10.1124 & 0.1554 & 0.0248 & 0.0125 & 0.2445 \\
$\mathrm{SD} \sigma_{\mathrm{a}}^{2}$ & $\mathrm{X}$ & 6.1616 & 0.0634 & 0.0081 & 0.0017 & 0.0959 \\
$\sigma_{\mathrm{a}}^{2}$ & urea & 4.3644 & 4.2202 & 4.1614 & 4.3364 & 4.1720 \\
$\mathrm{SD} \sigma_{\mathrm{a}}^{2}$ & urea & 0.6550 & 0.6808 & 0.6755 & 0.7553 & 0.5964 \\
$\mathrm{cov}$ & & -0.2614 & 0.0952 & 0.0199 & 0.0158 & 0.1213 \\
$\mathrm{SD}$ cov & & 1.1093 & 0.1821 & 0.0594 & 0.0126 & 0.1414 \\
\hline$\sigma_{\mathrm{pe}}^{2}$ & $\mathrm{X}$ & 17.0167 & 0.0961 & 0.0161 & 0.0053 & 0.1732 \\
$\mathrm{SD} \sigma_{\mathrm{pe}}^{2}$ & $\mathrm{X}$ & 1.7169 & 0.0300 & 0.0044 & 0.0020 & 0.0341 \\
$\sigma_{\mathrm{pe}}^{2}$ & urea & 4.3075 & 4.3137 & 4.3862 & 4.2472 & 4.3459 \\
$\mathrm{SD} \sigma_{\mathrm{pe}}^{2}$ & urea & 1.6056 & 1.6007 & 1.5820 & 1.5378 & 1.6520 \\
$\mathrm{cov}$ & & 3.5252 & 0.0433 & -0.0139 & 0.0205 & 0.0623 \\
$\mathrm{SD}$ cov & & 2.4330 & 0.0208 & 0.0201 & 0.0180 & 0.0363 \\
\hline$h_{\mathrm{a}}^{2}$ & $\mathrm{X}$ & 0.1834 & 0.2712 & 0.3272 & 0.3397 & 0.2978 \\
$\mathrm{SD} h_{\mathrm{a}}^{2}$ & & 0.0824 & 0.0967 & 0.0725 & 0.0379 & 0.0957 \\
\hline$h_{\mathrm{a}}^{2}$ & urea & 0.1588 & 0.1543 & 0.1519 & 0.1580 & 0.1528 \\
$\mathrm{SD} h_{\mathrm{a}}^{2}$ & & 0.0137 & 0.0176 & 0.0148 & 0.0175 & 0.0158 \\
\hline$r_{\mathrm{g}}$ & & -0.0973 & 0.1400 & 0.0377 & 0.0712 & 0.1250 \\
$\mathrm{SD} r_{\mathrm{g}}$ & & 0.1681 & 0.2059 & 0.1575 & 0.0547 & 0.1410 \\
\hline & & & & & &
\end{tabular}

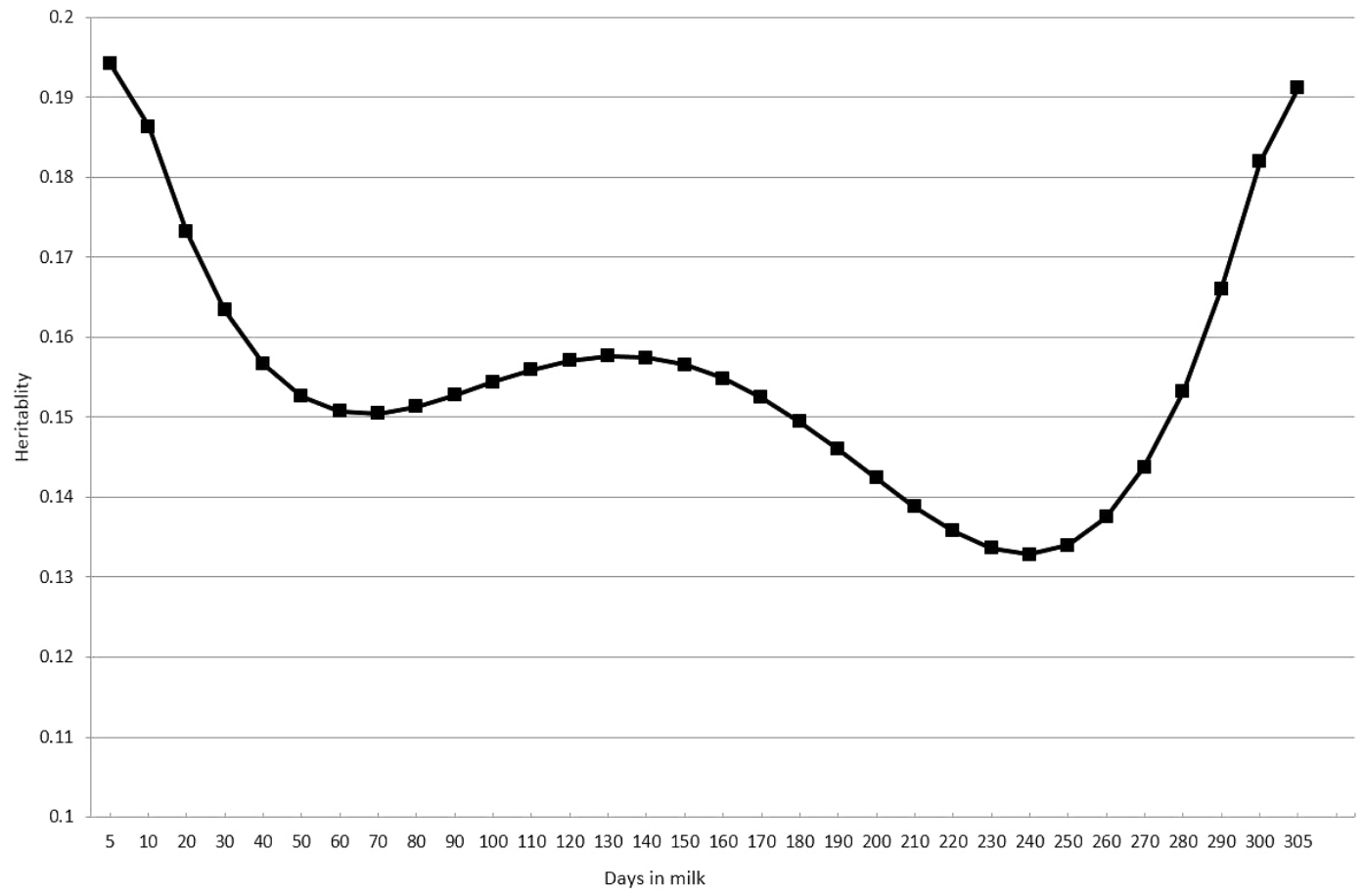

Figure 1. Daily heritability values for MU. 
of lactation. In the remaining lactation time, the MU heritability was clearly lower, at 0.133 to 0.157 . The heritability values shown in Fig. 1 confirm that there is a changing effect of genetic factors on MU during lactation. The resultant curve is similar to that presented by other authors in relation to milk yield and milk content (Nixon et al., 2009; Strabel and Misztal, 1999).

In conclusion, the present study shows highly significant influence of herd, year of calving, parity, lactation phase, and the level of milk performance on the urea content in cow's milk. It was noted that the high urea level in milk was detected in samples collected from older animals, during the winter season, and during the middle phase of lactation (101200 days).

The heritability estimates were generally at a low or moderate level, particularly in terms of milk yield and urea content, which may indicate the dominant role of the environment in shaping them. Relatively low values of genetic correlation between the urea content and other traits suggest that improvement in milk yield and its composition only modify the urea level in milk to a small degree.

Edited by: A.-E. Freifrau von Tiele-Winckler

Reviewed by: three anonymous referees

\section{References}

Aguilar, M., Hanigan, M. D., Tucker, H. .A, Jones, B. L. , Garbade, S. K., McGilliard, M. L., Stallings, C. C., Knowlton, K. F., and James, R. E.: Cow and herd variation in milk urea nitrogen concentrations in lactating dairy cattle, J. Dairy Sci., 12, 7261-7268, 2012.

Arunvipas, P., Dohoo, I. R., Van Leeuwen, J. A., and Keefe, G. P.: The effect of non-nutritional factors on milk urea nitrogen levels in dairy cows in Prince Edward Island, Canada, Prev. Vet. Med., 59, 83-93, 2003.

Bendelja, D., Prpić, Z., Mikulec, N., Ivkić, Z., Havranek, J., and Antunac, N.: Milk urea concentration in Holstein and Simmental cows, Mljekarstvo, 61, 45-55, 2011.

Biswajit, R., Brahma, B., Ghosh, S., Pankaj, P. K., and Mandal, G.: Evaluation of Milk Urea Concentration as Useful Indicator for Dairy Herd Management: A Review, Asian J. Anim. Vet. Adv., 6, 1-19, 2011.

Borkowska, D., Januś, E., and Wilgos, A.: The effect of selected factors on changes in body condition in high-yield cows, Acta Sci. Pol. Zootec., 11, 11-20, 2012.

Broderick, G. A. and Clayton, M. K.: A Statistical Evaluation of Animal and Nutritional Factors Influencing Concentrations of Milk Urea Nitrogen, J. Dairy Sci., 80, 2964-2971, 1997.

Canfield, R. W., Sniffen, C. J., and Butler, W. R.: Effects of Excess Degradable Protein on Postpartum Reproduction and Energy Balance in Dairy Cattle, J. Dairy Sci., 73, 2342-2349, 1990.

Carlsson, J., Bergström, J., and Pehrson, B.: Variations with breed, age, season, yield, stage of lactation and herd in the concentration of urea in bulk milk and individual cow's milk, Acta Vet. Scand., 36, 245-254, 1995.
Doska, M. C., da Silva, D. F. F., Horst, J. A., Valloto, A. A., Rossi Jr., P., and de Almeida, R.: Sources of variation in milk urea nitrogen in Paraná dairy cows, Rev. Bras. Zootec., 41, 692-697, 2012.

Fatehi, F., Zali, A., Honarvar, M., Dehghan-banadaky, M., Young, A. J., Ghiasvand, M., and Eftekhari, M.: Review of the relationship between milk urea nitrogen and days in milk, parity, and monthly temperature mean in Iranian Holstein cows, J. Dairy Sci., 95, 5156-5163, 2012.

Ferguson, J. D., Thomsen, N., Slesser, D., and Burris, D.: Pennsylvania DHIA milk urea testing, J. Dairy Sci., 80 (Suppl.), 161, 1997.

Frand, X., Froidmont, E., Bartiaux-Thill, N., Decruyenaere, V., Van Reusel, A., and Fabry, J.: Utilization of milk urea concentration as a tool to evaluate dairy herd management, Anim. Res., 52, 543-551, 2003.

Geerts, N. E., De Brabander, D. L., Vanacker, J. M., De Boever, J. L., and Botterman, S. M.: Milk urea concentration as affected by complete diet feeding and protein balance in the rumen of dairy cattle, Livest. Prod. Sci., 85, 263-273, 2004.

Gengler, N., Tijani, A., Wiggans, G. R., and Misztal, I.: Estimation of (Co)variance Function Coefficients for Test Day Yield with a Expectation-Maximization Restricted Maximum Likelihood Algorithm, J. Dairy Sci., 82, 1849-1872, 1999.

Godden, S. M., Lissemore, K. D., Kelton, D. F., Leslie, K. E., Walton, J. S., and Lumsden, J. H.: Factors Associated with Milk Urea Concentrations in Ontario Dairy Cows, J. Dairy Sci., 84, 107114, 2001.

Guo, K.: Effects of milk urea nitrogen and other factors on probability of conception of dairy cows. MSc thesis, University of Maryland, College Park, MD, USA, 2004.

Hojman, D., Kroll, O., Adin, G., Gips, M., Hanochi, B., and Ezra, E.: Relationships Between Milk Urea and Production, Nutrition, and Fertility Traits in Israeli Dairy Herds, J. Dairy Sci., 87, 10011011, 2004.

Hossein-Zadeh, N. G. and Ardalan, M.: Estimation of genetic parameters for milk urea nitrogen and its relationship with milk constituents in Iranian Holsteins, Livest. Sci., 135, 274-281, 2011.

Jamrozik, J. and Schaeffer, L. R.: Estimates of Genetic Parameters for Test Day Model with Random Regressions for Yield Traits of First Lactation Holstein, J. Dairy Sci., 80, 762-770, 1997.

Jílek, F., Řehák, D., Volek, J., Štípková, M., Němcová, E., Fiedlerová, M., Rajmon, R., and Švestková, D.: Effect of herd, parity, stage of lactation and milk yield on urea concentration in milk, Czech J. Anim. Sci., 51, 510-517, 2006.

Jonker, J. S., Kohn, R. A., and Erdman, R. A.: Milk Urea Nitrogen Target Concentrations for Lactating Dairy Cows Fed According to National Research Council Recommendations, J. Dairy Sci., 82, 1261-1273, 1999.

Jonkus, D. and Paura, L.: Estimation of Genetic Parameters for Milk Urea and Milk Production Traits of Latvian Brown Cows, Agric. Conspec. Sci., 76, 227-230, 2011.

Kgole, M. L., Visser, C., and Banga, C. B.: Environmental factors influencing milk urea nitrogen in South African Holstein cattle, S. Afr. J. Anim. Sci., 42 (Suppl.), 459-463, 2012.

Kohn, R. A., Kalscheur, K. F., and Russek-Cohen, E.: Evaluation of Models to Estimate Urinary Nitrogen and Expected Milk Urea Nitrogen, J. Dairy Sci., 85, 227-233, 2002. 
Kramer, M., Erbe, M., Bapst, B., Bieber, A., and Simianer, H.: Estimation of genetic parameters for individual udder quarter milk content traits in Brown Swiss cattle, J. Dairy Sci., 96, 59655976, 2013.

Křrižová, L., Hanuš, O., Roubal, P., Kučera, J., and Hadrová, S.: The effect of cattle breed, season and type of diet on nitrogen fractions and amino acid profile of raw milk, Arch. Tierz., 56, 709-718, 2013.

Misztal, I.: BLUPF90 family of programs, available at: http:// nce.ads.uga.edu/ ignacy/programs.html (last access: February 2015), 2007.

Mucha, S. and Strandberg, E.: Genetic analysis of milk urea nitrogen and relationships with yield and fertility across lactation, J. Dairy Sci., 94, 5665-5672, 2011.

Ng-Kwai-Hang, K. F., Hayes, J. F., Moxley, J. E., and Monardes, H. G.: Percentages of Protein and Nonprotein Nitrogen with Varying Fat and Somatic Cells in Bovine Milk, J. Dairy Sci., 68, 1257-1262, 1985.

Nixon, M., Bohmanova, J., Jamrozik, J., Schaeffer, L. R., Hand, K., and Miglior, F.: Genetic parameters of milking frequency and milk production traits in Canadian Holsteins milked by an automated milking system, J. Dairy Sci., 92, 3422-3430, 2009.

Oltner, R., Emanuelson, M., and Wiktorsson, H.: Urea concentrations in milk in relation to milk yield, live weight, lactation number and amount and composition of feed given to dairy cows, Livest. Prod. Sci., 12, 47-57, 1985.

Oudah, E. Z. M.: Non-genetic factors affecting somatic cell count, milk urea content, test-day milk yield and milk protein percent in dairy cattle of the Czech Republic using individual testday records. Livest Res Rural Dev 21, Article \#71, available at: http://www.lrrd.org/lrrd21/5/ouda21071.htm (last access: February 2015), 2009.

PFHBiPM: The results of breeding value of dairy cattle, Polish Federation of Cattle Breeders and Dairy Farmers, available at: http: //www.pfhb.pl/index.php/ocena/archiwum (last access: February 2015), 2012 (in Polish).
Rafieei, H.: Responses of Milk Urea Nitrogen Content to Dietary Rumen Degradable Protein Level in Lactating Holstein Dairy Cows, Iran J. Appl. Anim. Sci., 1, 111-116, 2011.

Rajala-Schultz, P. J. and Saville, W. J. A.: Sources of Variation in Milk Urea Nitrogen in Ohio Dairy Herds, J. Dairy Sci., 86, 1653 1661, 2003.

Rajala-Schultz, P. J., Saville, W. J. A., Frazer, G. S., and Wittum, T. E.: Association Between Milk Urea Nitrogen and Fertility in Ohio Dairy Cows, J. Dairy Sci., 84, 482-489, 2001.

Rodriguez, L. A., Stallings, C. C., Herbein, J. H., and McGilliard, M. L.: Effect of Degradability of Dietary Protein and Fat on Ruminal, Blood, and Milk Components of Jersey and Holstein Cows, J. Dairy Sci., 80, 353-363, 1997.

Rzewuska, K. and Strabel, T.: Genetic parameters for milk urea concentration and milk traits in Polish Holstein-Friesian cows, J. Appl. Genet., 54, 473-482, $2013 \mathrm{a}$.

Rzewuska, K. and Strabel, T.: Effects of some non-genetic factors on concentration of urea in milk in Polish Holstein-Fresian cows, J. Anim. Feed Sci., 22, 197-203, 2013b.

SAS: SAS/STAT ${ }^{\circledR} 9.4$ User's Guide, SAS Institute, Inc., Cary, NC, USA, 2013.

Sawa, A., Bogucki, M., and Krężel-Czopek, S.: Effect of some factors on relationships between milk urea levels and cow fertility, Arch. Tierz., 54, 468-476, 2011.

Strabel, T. and Misztal, I.: Genetic Parameters for First and Second Lactation Milk Yields of Polish Black and White Cattle with Random Regression Test-Day Models, J. Dairy Sci., 82, 28052810, 1999.

Wattiaux, M. A., Nordheim, E. V., and Crump, P.: Statistical Evaluation of Factors and Interactions Affecting Dairy Herd Improvement Milk Urea Nitrogen in Commercial Midwest Dairy Herds, J. Dairy Sci., 88, 3020-3035, 2005. 